\title{
Politik Hukum Pengaturan Pemerintahan Daerah yang Bersifat Khusus atau Bersifat Istimewa di Indonesia
}

\author{
Dianora Alivia \\ Magister Ilmu Hukum Universitas Padjadjaran \\ dianoraalivia11@gmail.com
}

\begin{abstract}
The principles contained in article $18 B$ paragraph (1) of the 1945 Constitution guarantee pluralism between regions so that there are possible pluralist arrangements under the concept of the Unitary State of the Republic of Indonesia. The problem that then arises is that the existence of special autonomy can potentially cause problems in a unitary state, one of which is when several regions propose their regions to become special autonomous regions. This study aims to determine the legal politics of the existence of special or special regions based on the 1945 Constitution and the direction and purpose of its formation. The research method used is a normative research method. The approach taken is the statue approach and historical approach. The results of the study indicate that the granting of specificity or privilege is limited to the Province of Aceh, Papua Province, West Papua Province, DKI Jakarta Province, and Yogyakarta Province. The direction of the policy limitation on the criteria of the regions which are designated as special or special regions shows that the implementation of regional autonomy is concerned with community plurality based on national interests in the framework of national unity and unity.
\end{abstract}

Keywords: Legal Policy, Unitary State, Asymmetrical Decentralization.

\begin{abstract}
Abstrak
Seiring berkembangnya praktik ketatanegaraan dalam bidang pemerintahan daerah, dalam penyelenggaraan otonomi daerah terdapat beberapa daerah yang diberikan kekhususan atau keistimewaan yang kemudian membedakan daerah tersebut dengan daerah lainnya. Hal tersebut dapat dilihat dalam ketentuan Pasal 18B ayat (1) UUD 1945. Prinsip yang terkandung dalam pasal 18B ayat (1) UUD 1945 menjamin pluralisme antar daerah yang sehingga dimungkinkan adanya pola-pola pengaturan yang bersifat pluralis di bawah konsep Negara Kesatuan Republik Indonesia. Permasalahan yang kemudian muncul adalah keberadaan otonomi khusus dapat berpotensi menimbulkan permasalahan dalam negara kesatuan, salah satunya ketika beberapa daerah-daerah mengajukan daerahnya untuk menjadi daerah otonomi khusus. Penelitian ini bertujuan untuk mengetahui politik hukum keberadaan daerah yang bersifat khusus atau bersifat istimewa berdasarkan UUD 1945 serta arah dan tujuan pembentukannya. Metode penelitian yang digunakan adalah metode penelitian normatif. Adapun pendekatan yang dilakukan adalah pendekatan perundang-undangan dan pendekatan sejarah). Hasil penelitian menunjukkan bahwa pemberian kekhususan atau keistimewaan tersebut
\end{abstract}


dibatasi kepada Provinsi Aceh, Provinsi Papua, Provinsi Papua Barat, Provinsi DKI Jakarta, dan Provinsi Yogyakarta. Arah kebijakan pembatasan terhadap kriteria daerah yang ditetapkan sebagai daerah yang bersifat khusus atau bersifat istimewa menunjukkan pelaksanaan otonomi daerah memperhatikan kemajemukan masyarakat didasarkan pada kepentingan nasional dalam rangka kesatuan dan persatuan bangsa.

\section{Kata Kunci: Politik Hukum, Negara Kesatuan, Desentralisasi Asimetris.}

\section{Pendahuluan}

Indonesia merupakan negara yang memiliki kebhinekaan dalam suku yang berjumlah lebih dari 1.128 (seribu seratus dua puluh delapan) suku bangsa dan lebih dari 700 bahasa daerah. (Tim Kerja Sosialisasi MPR, 2012: 185). Keberagaman tersebut membuat bangsa Indonesia menjadi bangsa kaya akan budaya yang beranekaragam. Kondisi yang demikian membuat tiap-tiap daerah di Indonesia memiliki kebutuhan khusus yang berbeda-beda untuk mengembangkan potensi yang ada pada daerahnya. Dengan kondisi yang demikian para pendiri bangsa memutuskan untuk menjadikan Indonesia sebagai negara kesatuan.

Pilihan bentuk negara atau pilihan susunan kenegaraan pada umumnya, bukan sekedar pertimbangan teknis atau pertimbangan praktis. Pilihan itu ditentukan pula oleh pertimbangan politik, pertimbangan pengalaman, pertimbangan kesejarahan, kenyataan sosial budaya dan lain sebagainya. Dengan berbagai pertimbangan politik dan dasar-dasar sosio kultur tersebut, bukanlah sesuatu yang sulit untuk membentuk bangsa Indonesia dalam wadah negara kesatuan (Bagir Manan, 2005: 22). Oleh karena itu kemudian Pasal 1 ayat (1) UndangUndang Dasar Negara Republik Indonesia Tahun 1945 (selanjutnya disebut dengan UUD 1945) mengukuhkan keberadaan Indonesia sebagai negara kesatuan.

Mengingat kenyataan wilayah negara Indonesia memiliki sosio kultur yang beragam, maka untuk menyatukan keberagaman tersebut pemerintah memberikan kesempatan seluas-luasnya kepada daerah-daerah untuk mengembangkan daerahnya dalam negara kesatuan dengan 
desentralisasi yang berinti pokok atau bertumpu pada otonomi.

Sejak awal kemerdekaan, politik hukum otonomi daerah senantiasa digariskan melalui proses yang tak pernah selesai. Ia selalu berubah dan diubah sesuai dengan perubahan konfigurasi politik. Perubahan itu menyangkut berbagai aspek dalam sistem otonomi, seperti aspek formal, materiil, nyata, seluas-luasnya, hubungan kekuasaan, cara pemilihan dan sebagainya, yang dalam praktiknya di lapangan senantiasa menimbulkan masalah yang berbenturan dengan budaya dan perilaku politik yang mengalami tolak tarik antara elite dan massa. (Abdul Latif, Hasbi Ali, 2010: 96).

Menurut Mahfud MD, politik hukum adalah legal policy atau arah hukum yang akan diberlakukan oleh negara untuk mencapai tujuan negara yang bentuknya dapat berupa pembuatan hukum baru dan penggantian hukum lama (Mahfud MD, 2017: 5). Berdasarkan pendapat tersebut, politik hukum otonomi daerah harus dibangun berdasarkan Pancasila dan UUD 1945 dengan memperhatikan kemajemukan masyarakat demi kesejahteraan umum. Keberadaan otonomi daerah secara khusus diatur dalam Bab VI tentang Pemerintahan Daerah untuk mencapai cita-cita negara yang terkandung dalam pembukaan UUD 1945.

Seiring berkembangnya praktik ketatanegaraan dalam bidang pemerintahan daerah, dalam penyelenggaraan otonomi daerah terdapat beberapa daerah yang diberikan kekhususan atau keistimewaan yang kemudian membedakan daerah tersebut dengan daerah lainnya. Hal tersebut dapat dilihat dalam ketentuan Pasal 18B ayat (1) UUD 1945 menyatakan, "Negara mengakui dan menghormati satuan-satuan Pemerintahan Daerah yang bersifat khusus atau bersifat istimewa yang diatur dengan undang-undang." Prinsip yang terkandung dalam pasal 18B ayat (1) UUD 1945 menjamin pluralisme antar daerah yang sehingga dimungkinkan adanya pola-pola pengaturan yang bersifat pluralis di bawah konsep Negara Kesatuan Republik Indonesia. 
Pemerintahan Daerah yang bersifat khusus terdiri dari 4 daerah, yaitu Provinsi Aceh, Provinsi Papua, Provinsi Papua Barat, dan Provinsi DKI Jakarta. Sedangkan daerah yang bersifat istimewa, yaitu Provinsi Aceh dan Provinsi Daerah Istimewa Yogyakarta. Asal kekhususan dan keistimewaan 5 (lima) tersebut berasal dari hak asal-usul dan sejarah yang kemudian diakui dan ditetapkan dengan peraturan undang-undang sebagai bagian dari Negara Kesatuan Republik Indonesia. Dengan kekhususan dan keistimewaannya, daerah tersebut diperlakukan berbeda dengan daerah otonom lainnya yang hanya bersifat administratif belaka, namun daerah tersebut tetaplah daerah dan bukan negara bagian yang memiliki konstitusi tersendiri (Erdianto, Rika Lestari, 2008: 55).

Jenis dan ruang lingkup kekhususan atau keistimewaan daerah yang ditetapkan dengan undang-undang sangat terkait dengan hak asal-usul yang melekat pada daerah yang telah diakui tetap hidup dan latar belakang pembentukan dan kebutuhan nyata diperlukannya kekhususan dan keistimewaan dari daerah yang bersangkutan. Dengan memperhatikan kriteria tersebut maka hak asal-usul dan sejarah 5 (lima) daerah tersebut harus tetap diakui sebagai daerah yang memiliki kekhususan dan keistimewaan yang berbeda dari daerah-daerah lainnya.

Permasalahan yang kemudian muncul adalah, baik secara teoretis maupun pada tataran empiris, keberadaan otonomi khusus dapat berpotensi menimbulkan permasalahan dalam negara kesatuan. Menurut Hannum, sumber permasalahan yang terutama adalah apabila baik pemerintah nasional maupun kelompok minoritas yang bermaksud meminta, atau telah diberikan status otonomi khusus itu sama-sama tidak memahami apa saja yang seharusnya menjadi isi otonomi tersebut terutama dalam kaitannya dengan upaya bersama untuk memecahkan masalah nasional, atau secara lebih khusus masalah ancaman disintegrasi yang tidak bisa diabaikan secara nasional. Keadaan dapat menjadi lebih buruk apabila timbul kecemburuan sosial dari rakyat di wilayah-wilayah lain yang memandang otonomi khusus itu 
identik dengan pilihkasih yang ditunjukkan pemerintah pusat kepada rakyat di wilayah tertentu, atau apabila pemberlakuan otonomi khusus itu menambah beban wilayah-wilayah lain itu (Ni'matul Huda, 2014: 65).

Hal tersebut terbukti dengan timbulnya suatu permasalahan ketika beberapa daerah-daerah mengajukan daerahnya untuk menjadi daerah otonomi khusus. Dalam pergolakan isu otonomi daerah pasca Orde Baru, pada 29-30 Januari 2000 Kongres Rakyat Riau II menyepakati untuk memilih opsi 'Riau Merdeka' (yang diusung oleh Dr. Tabrani Rab dan Fauzi Kadir), otonomi khusus atau negara federal. Opsi 'Riau Merdeka' kala itu merupakan cermin keresahan masyarakat Riau yang konon kaya akan sumber daya alam tetapi pembangunannya terlalu jauh ketinggalan. Kemiskinan, ketertinggalan tingkat pendidikan, rendahnya kualitas tenaga kerja, lemahnya akses ke sumber daya alam, lenyapnya tanah-tanah ulayat, adalah berbagai sebab masyarakat Riau telah kehabisan kesabaran untuk berdiam diri (Husnu Abadi, 2003: 9).

Terakhir pada tahun 2017 muncul keinginan daerah Batam menjadi daerah otonomi khusus perekonomian dengan alasan, Batam sebagai daerah lokomotif perekonomian nasional selama ini hanya menjadi alat bagi daerah lain di Kepulauan Riau (Media Indonesia, 2 September 2017).

\section{Metode Penelitian}

Dalam penelitian ini menggunakan Jenis penelitian yang digunakan dalam penulisan penelitian ini menggunakan jenis penelitian normatif. Penelitian normatif adalah penelitian hukum yang mencakup penelitian terhadap azas-azas hukum, penelitian terhadap sistematika hukum, penelitian terhadap taraf sinkhronisasi hukum, penelitian sejarah hukum, dan penelitian perbandingan hukum (Soerjono Soekanto, 1981: 51). Selanjutnya pendekatan penelitian yang digunakan menggunakan jenis pendekatan perundang-undangan (statue approach), dan pendekatan sejarah (historical approach). 
Hasil dan Pembahasan

Politik Hukum Pengaturan Pemerintahan Daerah yang Bersifat Khusus atau Bersifat Istimewa Menurut UUD 1945

Dalam konteks bentuk negara, meskipun negara Indonesia memilih bentuk negara kesatuan, tetapi di dalamnya terselenggara suatu mekanisme yang memungkinkan tumbuh berkembangnya keragaman antar daerah di seluruh tanah air. Kekayaan alam dan budaya antar daerah tidak boleh diseragamkan dalam struktur NKRI. Dengan perkataan lain, bentuk NKRI diselenggarakan dengan jaminan otonomi yang seluas-luasnya kepada daerah-daerah untuk berkembang sesuai dengan potensi dan kekayaan yang dimilikinya masing-masing, tentunya dengan dorongan, dukungan, dan bantuan yang diberikan oleh Pemerintah Pusat (Jimly Asshiddiqie, 2011: 79).

Negara kesatuan adalah bentuk kenegaraan yang paling kokoh, jika dibandingkan dengan federal atau konfederasi. Dalam negara kesatuan terdapat persatuan (union) maupun kesatuan (unity) (Fred Isjwara, 1974: 188). Dilihat dari segi susunan negara kesatuan, maka negara kesatuan bukan negara yang tersusun dari beberapa negara melainkan negara tunggal.

Dapat dikatakan bahwa bentuk negara yang paling ideal bagi negara yang mempunyai banyak keragaman suku bangsa, agama, dan budaya seperti halnya Indonesia adalah bentuk negara kesatuan dengan sistem desentralisasi. Dengan demikian maka tiap daerah dapat melakukan eksplorasi terhadap potensi-potensi yang terdapat pada daerahnya sehingga setiap daerah mempunyai ciri khas yang berbeda dan dapat memaksimalkan upaya pelaksanaan pembangunan di Indonesia.

Di Indonesia, prinsip persatuan sangat dibutuhkan karena keragaman suku, ras, agama, dan budaya yang diwarisi oleh bangsa Indonesia dalam sejarah, yang mengharuskan bangsa Indonesia bersatu dengan seerateratnya dalam keragaman itu. Keragaman itu merupakan kekayaan yang harus dipersatukan (united), tetapi tidak boleh disatukan atau diseragamkan (uniformed). Oleh karena itu, prinsip persatuan 
Indonesia tidak boleh diidentikkan dengan kesatuan. Prinsip persatuan juga tidak boleh disempitkan maknanya ataupun diidentikkan dengan pengertian pelembagaan bentuk negara kesatuan yang merupakan bangunan negara yang dibangun atas motto Bhineka Tunggal Ika (Unity In Diversity) (Jimly Asshiddiqie, 2011: 64).

Ketika para pendiri negara yang tergabung dalam Badan Penyelidik Usaha-Usaha Persiapan Kemerdekaan Indonesia (BPUPKI), yang kemudian diusul dengan Panitia Persiapan Kemerdekaan Indonesia (PPKI), berembuk untuk membentuk negara Indonesia, maka pilihan mereka jatuh kepada prinsip demokrasi dengan bentuk negara kesatuan dan bentuk pemerintahan republik (Pasal 1 ayat (1) UUD 1945). Dengan demikian, politik hukum yang pertama mengenai hubungan pusat dan daerah yang dianut di dalam konstitusi Indonesia adalah politik hukum negara kesatuan. Selanjutnya, Pasal 18 UUD 1945 menegaskan mengenai hubungan antara pusat dan daerah dengan politik hukum desentralisasi (otonomi) dan dekonsentrasi dengan susunan berjenjang dan dengan memperhatikan hak asal-usul dan bersifat istimewa. Itulah dua garis utama politik hukum otonomi daerah di negara Republik Indonesia (Abdul Latif, Hasbi Ali, 2010: 96).

Dari kedua pasal tersebut, yakni Pasal 1 ayat (1) dan Pasal 18 UUD 1945 terdapat hal yang saling berkaitan antara satu sama lain. Meskipun Pasal 18 menyatakan bahwa wilayah negara Indonesia dibagi atas daerah-daerah otonom dan wilayah administrasi yang dapat mengatur dan mengurus rumah tangganya sendiri, maka Pasal 1 ayat (1) merupakan penegas bahwa Indonesia tetap merupakan sebuah negara yang berbentuk negara kesatuan.

Selain adanya Pemerintahan Daerah di Negara Kesatuan, terdapat pula Pemerintahan daerah yang bersifat khusus atau bersifat istimewa. Keberadaan Pemerintahan daerah yang bersifat khusus atau bersifat istimewa tersebut secara tegas disebutkan dalam Pasal 18B UUD 1945. Prinsip yang terkandung dalam Pasal 18B merupakan 
pengakuan negara terhadap pula provinsi juga harus Pemerintahan daerah yang bersifat berkoordinasi dengan pemerintah khusus atau bersifat istimewa dan pusat sehingga yang menjadi pusat prinsip eksistensi dan hak-hak pemerintahan di sini bukanlah tradisional masyarakat adat. Adanya kewenangan khusus dalam Pemerintahan daerah yang bersifat khusus atau bersifat istimewa untuk menghormati eksistensi hak-hak tradisional masyarakat adat.

Meski demikian, mengingat Pemerintahan daerah yang bersifat khusus atau bersifat istimewa di Indonesia disebutkan dalam Bab VI tentang Pemerintahan Daerah, maka kedudukan Pemerintahan daerah yang bersifat khusus atau bersifat istimewa adalah sejajar dengan Pemerintahan Daerah yaitu merupakan daerah-daerah otonom yang tunduk dan bertanggungjawab kepada Pemerintah Pusat.

Pembagian hubungan antara pemerintah pusat dan pemerintah daerah yang juga di dalamnya termasuk pemerintahan daerah yang bersifat khusus atau bersifat istimewa tersebut bersifat hierarkis dengan pola bottom-up, artinya daerah kabupaten dan kota harus berkoordinasi dengan provinsi begitu pemerintahan daerah melainkan pemerintah pusat sebagai puncak kekuasaan tertinggi dalam suatu negara.

Koordinasi kerja yang hierarkis antara Pemerintahan Pusat dan Pemerintahan Daerah diselenggarakan dengan prinsip otonomi daerah yang seluas-luasnya. Desentralisasi dan dekonsentrasi dalam otonomi daerah pada hakekatnya tidak lebih dari suatu sarana atau cara untuk melakukan pemerintahan di daerah dengan cara sebaik-baiknya. Bagir Manan berpendapat, hubungan antara Pusat dan Daerah dalam kerangka desentralisasi didasarkan kepada: dasar permusyawaratan dalam sistem pemerintahan negara; dasar pemeliharaan dan pengembangan prinsip-prinsip pemerintahan asli; dasar kebhinekaan; dan dasar negara hukum (Irawan Soejito, 1984: 4). Pemerintah Daerah Kabupaten dan/atau Kota serta Pemerintah Provinsi merupakan perpanjangan 
tangan dari Pemerintah Pusat untuk membantu Pemerintah Pusat melaksanakan roda pemerintahan.

Namun yang perlu diperhatikan, betapapun luasnya otonomi daerah untuk mengatur dan mengurus rumah tangga daerah, tidak boleh mangakibatkan rusaknya hubungan antar Pemerintah Daerah dengan Pemerintah Pusat dari Negara Kesatuan (Ateng Syafrudin, 1993: 186) Oleh karena itu konstitusi memberikan penegasan batasan Pemerintahan Daerah dalam menjalankan otonominya pada Pasal 18 ayat (5) UUD 1945.

Pasal 18B ayat (5) UUD 1945 merupakan bentuk pembatasan yang sesuai dengan prinsip negara kesatuan yaitu bahwa pemerintah pusat yang mempunyai kekuasaan serta wewenang tertinggi dalam bidang pemerintahan negara, menetapkan kebijaksanaan pemerintahan dan melaksanakan pemerintahan negara baik di pusat maupun di daerah (Rusdianto Sesung, 2013: 49).

Seberapapun luasnya otonomi daerah yang dimiliki oleh Pemerintahan daerah yang bersifat khusus atau bersifat istimewa dalam sebuah negara kesatuantidak akan pernah menjadikannya sebagai sebuah negara bagian karena wewenang tertinggi dalam negara kesatuan adalah pemerintahan pusat.

Dalam kajian politik hukum, jika hukum diartikan sebagai "alat" untuk meraih cita-cita dan mencapai tujuan, maka politik hukum diartikan sebagai arah yang harus ditempuh dalam pembuatan dan penegakan hukum guna mencapai cita-cita dan tujuan bangsa. (Mahfud MD, 2017: 30). Menurut Bagir Manan, landasan filosofis politik hukum otonomi daerah selain demokrasi atau kerakyatan (kerakyatan yang dipimpin oleh hikmat kebijaksanaan dalam permusyawaratan/ perwakilan), paling tidak ada dua dasar lain dari sila Pancasila yaitu Persatuan Indonesia dan Keadilan Sosial (Bagir Manan, 26 September 2013). Dengan demikian, maka politik hukum pemerintahan daerah yang bersifat khusus atau bersifat istimewa harus berpijak kepada kerangka dasar politik hukum nasional yang mengarah pada citacita bangsa yakni masyarakat adil 
dan makmur berdasarkan Pancasila dalam bingkai negara kesatuan.

\section{Arah dan Tujuan Pembentukan Pemerintahan Daerah yang Bersifat Khusus atau Bersifat Istimewa}

Bentuk negara yang paling ideal bagi negara yang mempunyai banyak keragaman suku bangsa, agama, dan budaya seperti halnya Indonesia adalah bentuk negara kesatuan dengan sistem desentralisasi. Dengan demikian maka tiap daerah dapat melakukan eksplorasi terhadap potensi-potensi yang terdapat pada daerahnya sehingga setiap daerah mempunyai ciri khas yang berbeda dan dapat memaksimalkan upaya pelaksanaan pembangunan di Indonesia.

Asas desentralisasi dikenal terbagi dalam 2 (dua) kategori, yaitu selain desentralisasi simetris (symetric decentralization), juga dikenal desentralisasi asimetris (asymetric decentralization) atau otonomi khusus. Sebagaimana dikemukakan oleh Joachim Wenher, bahwa pemberian otonomi yang berbeda atas satu daerah atau wilayah dari beberapa daerah merupakan praktek penyelenggaraan pemerintahan yang cukup umum ditemui dalam pengalaman pengaturan politik di banyak negara. Pengalaman ini berlangsung baik di dalam bentuk negara kesatuan yang didesentralisasikan, maupun dalam format pengaturan federatif.

Secara prinsipil, berbagai bentuk penyebaran kekuasaan yang bercorak asimetris di atas merupakan salah satu instrumen kebijakan yang dimaksudkan untuk mengatasi dua hal lain fundamental yang dihadapi suatu negara, yakni permasalahan bercorak politik, termasuk yang bersumber pada keunikan dan perbedaan budaya; dan persoalan yang bercorak teknokratismenejerial, yakni keterbatasan kapasitas suatu daerah atau suatu wilayah dalam menjalankan fungsi dasar pemerintahan. Sementara, menurut Peter Harris dan Ben Reilly, melalui desentralisasi asimetris ini, wilayah-wilayah tertentu di dalam suatu negara diberikan kewenangan khusus yang tidak diberikan kepada wilayah-wilayah lain (Agung Djojosoekarto, dkk, 2008: 10). 
Di dalam Bab VI UUD 1945 (sebelum perubahan) tentang Pemerintahan Daerah, sudah ditentukan pengaturan daerah di Indonesia secara asimetris. Hal itu terihat dalam rumusan Pasal 18 UUD 1945 sebelum perubahan. Selanjutnya di dalam Penjelasan disebutkan bahwa daerah-daerah yang bersifat istimewa mencakup "zelfbesturende landschappen" (swapraja), dan "volksgemeenshappen" (desa, marga, dan lain-lain". Dengan demikian, yang dimaksud "bersifat istimewa" adalah pemerintahan asli atau pemerintahan bumiputra. Tidak ada daerah khusus. Dalam praktik dikenal daerah istimewa (Yogyakarta dan Aceh).

Apakah perbedaan antara faktor kekhususan dengan faktor istimewa? Kalau mengikuti Penjelasan Pasal 18 UUD 1945 sebelum perubahan, pengertian istimewa dikaitkan dengan pemerintahan asli seperti desa atau pemerintahan yang diselenggarakan pribumi seperti Daerah Istimewa Yogyakarta (dimasa penjajahan). Tetapi dengan pembentukan Daerah Istimewa Aceh, pengertian istimewa bergeser. Tidak lagi semata-mata menunjuk pemerintahan asli atau yang diselenggarakan pribumi di masa penjajahan. Seperti telah dikemukakan, Daerah Istimewa Aceh bertalian dengan pelaksanaan syariat Islam. Demikian pula pengertian "khusus". Tidak ada sebutan "khusus" dalam UUD 1945 (sebelum perubahan). Kemudian pada perubahan kedua UUD 1945 barulah sebutan "khusus" muncul dalam Pasal 18B UUD 1945 (Bagir Manan, 2005: 15).

Sekarang pengertian kekhususan diperluas mencakup Provinsi Aceh, Provinsi Papua, Provinsi Papua Barat, dan Provinsi DKI Jakarta. Perluasan-perluasan pengertian ini bukan mengandung resiko. Tidak ada lagi satu kriteria baku. Setiap daerah dapat menuntut suatu kekhususan, semata-mata berdasarkan faktorfaktor tertentu tanpa suatu kriteria umum yang telah ditentukan dalam undang-undang.

Jika merujuk kepada pendapat Tarlton tentang desentralisasi asimetris, ia membagi konsep desentralisasi asimetris menjadi dua 
jenis asyimetrical federation, yaitu asimetri de jure dan asimetri de facto yang ditandai dengan perbedaan pada tingkat otonomi. Istilah asimetri de jure mengacu pada kondisi di mana terdapat penegasan praktek asimetrisme dalam konstitusi. Artinya, dalam konstitusi yang sah sudah ditekankan bahwa terdapat unit-unit konstituen yang diperlakukan berbeda di bawah hukum yang sudah ditetapkan. Dalam asimetri de jure, kebijakan dan penentuan perlakuan asimetri kepada masing-masing daerah ditentukan oleh beberapa syarat yang ditetapkan pusat. Adapun istilah asimetri de facto, mengacu pada perbedaan praktek nyata atau hubungan antar daerah yang muncul karena perbedaan keadaan sosial, budaya, dan ekonomi. Pada pengaplikasian asimetri de facto, tidak ada keterjaminan hukum atau standar yang relevan, melainkan pada prakteknya sudah lazim dan diterima (Krismiyati Tasrin, dkk, 2012: 12).

Meski pada awalnya Tarlton menulis tema asimetris dalam kerangka negara federal, dalam perkembangannya dikemudian hari menunjukkan bahwa konsep dan penerapan kebijakan atas model tersebut mulai diadopsi di negara kesatuan. Jika demikian, dapat dikatakan desentralisasi asimetris yang digunakan Indonesia pada prakteknya adalah desentralisasi asimetri de facto mengingat tidak ada standar baku penetapan daerah yang bersifat khusus atau bersifat istimewa namun pada prakteknya keberadaan Provinsi Aceh, Provinsi Papua, Provinsi Papua Barat, Provinsi Daerah Istimewa Yogyakarta (DIY), dan Provinsi Daerah Khusus Ibukota Jakarta (DKI Jakarta) telah diterima sebagai daerah yang bersifat khusus atau bersifat istimewa.

Jika ditinjau dari sejarah pembentukan Pasal 18B ayat (1) UUD 1945, terlihat bahwa sebutan daerah yang bersifat khusus ini telah dibatasi keberadaannya hanya untuk Provinsi Aceh, Provinsi Papua dan Provinsi Papua Barat. Daerah yang bersifat khusus hanya untuk Provinsi DIY, sedangkan Provinsi DKI Jakarta mendapatkan kekhususan karena keberadaannya sebagai Ibu 
Kota Negara Indonesia. Adapun pembatasan terhadap daerah yang bersifat khusus atau bersifat istimewa terlihat dalam rapat PAH I BP MPR yang terdokumentasi dalam naskah komprehensif proses dan perubahan UUD 1945.

Dalam pembahasan mengenai perubahan Pasal 18, khususnya yang menyangkut daerah yang bersifat khusus atau bersifat istimewa, hampir semua anggota PAH I BP MPR sepakat bahwa keberadaan daerah khusus atau daerah istimewa tersebut harus tetap dipertahankan.

Mengenai pengaturan kriteria daerah otonom yang bersifat khusus dan istimewa, Hobbes Sinaga dari Fraksi PDIP berpendapat :

“. . . negara mengakui keberadaan daerah otonom yang bersifat khusus dan istimewa yang telah diatur dengan undang-undang. justru jangan sampai ada lagi, kita sudah cukup punya Jogja, punya Papua sama punya Aceh, sudah jangan sampai ada lagi. Yang lain sama. Jadi, makanya sudah diatur, tutup saja di sini maksud saya. Sudah ada Tap MPR" (Tim
Penyusun Naskah Komprehensif Proses dan Hasil Perubahan UUD 1945, 2010: 1189).

Pelaksanaan daerah yang bersifat khusus atau bersifat istimewa di Indonesia harus memiliki pembatasan terhadap kriteria dan jumlah daerah yang ditetapkan sebagai daerah yang bersifat khusus atau bersifat istimewa agar tidak menimbulkan konflik. Ida Bagus Adyanan Manuaba dalam rapat PAH I BP MPR berpendapat bahwa daerah yang bersifat khusus atau bersifat istimewa hanya diberikan pada Yogyakarta, Irian dan Aceh untuk menghindari munculnya daerah-daerah lain mengajukan diri sebagai daerah otonomi khusus dan kemudian menjadi sumber federasi dalam negara kesatuan.

Ditinjau dari kajian politik hukum, keputusan para perumus UUD 1945 pada rapat PAH I BP MPR tersebut didasarkan pada politik hukum negara kesatuan dan politik hukum otonomi daerah sebagaimana yang telah dijabarkan sebelumnya. Politik hukum dalam otonomi daerah dalam peraturan 
perundang-undangan yang bersifat tetap antara lain :

1) Ada satu kesatuan sistem hukum Indonesia;

2) Sistem hukum nasional dibangun berdasarkan untuk memperkokoh sendi-sendi Pancasila dan UUD 1945;

3) Tidak ada hukum yang memberikan hak-hak istimewa pada warga negara tertentu berdasarkan suku, ras atau agama. Kalaupun ada perbedaan semata-mata didasarkan pada kepentingan nasional dalam rangka kesatuan dan persatuan bangsa;

4) Pembentukan hukum memperhatikan kemajemukan masyarakat;

5) Hukum adat dan hukum tidak tertulis lainnya diakui sebagai subsistem hukum nasional sepanjang nyata-nyata hidup dan dipertahankan dalam pergaulan masyarakat;

\section{Simpulan}

Keberadaan pemerintahan daerah yang bersifat khusus atau bersifat istimewa harus berpijak
6) Pembentukan hukum sepenuhnya didasarkan pada parisipasi masyarakat; dan

7) Hukum dibentuk dan ditegakkan demi kesejahteraan umum (keadilan sosial bagi seluruh rakyat), terwujudnya masyarakat yang demoratis dan mandiri serta terlaksananya negara berdasrkan atas hukum dan berkonstitusi (Bagir Manan, 2005: 179).

Arah kebijakan pembatasan terhadap kriteria daerah yang ditetapkan sebagai daerah yang bersifat khusus atau bersifat istimewa menunjukkan pelaksanaan otonomi daerah memperhatikan kemajemukan masyarakat didasarkan pada kepentingan nasional dalam rangka kesatuan dan persatuan bangsa demi mewujudkan keadilan sosial bagi seluruh rakyat Indonesia.

kepada kerangka dasar politik hukum nasional yang mengarah pada citacita bangsa yakni masyarakat adil dan makmur berdasarkan Pancasila 
dan UUD 1945 dalam bingkai negara kesatuan.

Untuk mencegah banyaknya daerah yang mengajukan daerahnya sebagai pemerintahan daerah yang bersifat khusus atau bersifat istimewa, sebaiknya pemerintah menegaskan perihal keberadaan pemerintahan daerah yang bersifat khusus atau bersifat istimewa dalam peraturan perundang-undangan bahwa daerah pemerintahan daerah yang bersifat khusus atau bersifat istimewa hanya berlaku untuk Provinsi Aceh, Provinsi Papua, Provinsi Papua Barat, dan Provinsi DIY dan keberadaannya tidak dapat diganggu gugat. Sedangkan Jakarta, menjadi daerah yang bersifat khusus karena keberadaannya sebagai ibu kota sehingga apabila tidak menjadi ibu kota lagi maka kekhususannya dapat dicabut.

\section{Daftar Pustaka}

\section{Buku}

Latif , Abdul; Ali, Hasbi, 2010, Politik Hukum, Jakarta: Sinar Grafika Offset.

Djojosoekarto, Agung, dkk, 2008, Kebijakan Otonomi Khusus di Indonesia, Pembelajaran dari Kasus Aceh, Papua, Jakarta, dan Yogyakarta, Jakarta: Kemitraan.

Syafrudin , Ateng, 1993, Pengaturan Koordinasi Pemerintahan Di Daerah, Bandung: Citra Aditya Bakti.

Manan, Bagir, 1994, Hubungan Antara Pusat dan Daerah Menurut UUD 1945, Jakarta: Pustaka Sinar Harapan. , 2005, Menyongsong Fajar Otonomi, Yogyakarta: Pusat Studi Hukum Fakultas Hukum UII Yogyakarta.

Isjwara, Fred, 1974, Pengantar Ilmu Politik, Bandung: Bina Cipta.

Abadi , Husnu, 2003, Mencari Format Otonomi Khusus Buat Provinsi Riau, Pekanbaru: UIR Press.

Soejito, Irawan, 1984, Hubungan Pemerintah Pusat dan Pemerintah Daerah, Jakarta: Bina Aksara.

Asshiddiqie, Jimly, 2011, Konstitusi dan Konstitusionalisme di Indonesia, Jakarta: Sinar Grafika.

Tasrin , Krismiyati, dkk, 2012, Kajian Pengembangan Desentralisasi Asimetris di Indonesia, Bandung: Pusat Kajian Pendidikan dan Pelatihan Aparatur I 
Lembaga Administrasi Negara.

MD, Mahfud, 2017, Membangun Politik Hukum, Menegakkan Konstitusi, Depok: PT RajaGrafindo Persada.

Huda, Ni'matul, 2014, Desentralisasi Asimetris Dalam NKRI (Kajian Terhadap Daerah Istimewa, Daerah Khusus dan Otonomi Khusus, Bandung: Nusa Medua.

Pimpinan MPR dan Tim Kerja Sosialisasi MPR Periode 2009-2014, 2012, Empat Pilar Berbangsa dan Bernegara, Jakarta: Sekretariat Jenderal MPR RI.

Sesung, Rusdianto, 2013, Hukum Otonomi Daerah: Negara Kesatuan, Daerah Istimewan dan Daerah Otonomi Khusus, Bandung: Refika Aditama.

Soekanto, Soerjono, 1981, Pengantar Penelitian Hukum, Jakarta, UI Press.

Tim Penyusun Naskah Komprehensif Proses dan Hasil Perubahan UUD 1945, 2010, Naskah Komprehensif Perubahan Undang-Undang Dasar Negara Republik Indonesia Tahun 1945 : Buku IV Kekuasaan Pemerintan Negara Jilid 2, Jakarta: Sekretariat Jenderal Mahkamah Konstitusi.

\section{Jurnal}

Erdianto; Lestari, Rika, Otonomi Khusus dalam Perspektif UUD 1945, Jurnal Konstitusi Fakultas Hukum Universitas Riau bekerkajasama dengan Mahkamah Konstitusi Republik Indonesia.

\section{Peraturan Perundang-Undangan}

Undang-Undang Dasar Negara Republik Indonesia Tahun 1945.

Undang-Undang Republik Indonesia Nomor 23 Tahun 2014 tentang Pemerintahan Daerah (Lembaran Negara Republik Indonesia Tahun 2014 Nomor 244, Tambahan Lembaran Negara Republik Indonesia Nomor 5587).

Undang-Undang Republik Indonesia Nomor 13 Tahun 2012tentang Keistimewaan Daerah Istimewa Yogyakarta (Lembaran Negara Republik Indonesia Tahun 2012 Nomor 170, Tambahan Lembaran Negara Republik Indonesia Nomor 5339).

Undang-Undang Republik Indonesia Nomor 35 Tahun 2008 tentang Penetapan Peraturan Pemerintah Pengganti Undang-Undang Nomor 1 Tahun 2008 Tentang Perubahan Atas UndangUndang Nomor 21 Tahun 2001 Tentang Otonomi Khusus Bagi Provinsi Papua 
Menjadi Undang-Undang (Lembaran Negara Republik Indonesia Tahun 2008 Nomor 112, Tambahan Lembaran Negara Republik Indonesia Nomor 4884).

Undang-Undang Republik Indonesia

Nomor 29 Tahun 2007

tentang Pemerintahan

Provinsi Daerah Khusus

Ibukota Jakarta Sebagai

Ibukota Negara Kesatuan

Republik Indonesia

(Lembaran Negara Republik

Indonesia Tahun 2007

Nomor 93, Tambahan

Lembaran Negara Republik Indonesia Nomor 4744).

Undang-Undang Republik Indonesia Nomor 11 Tahun 2006 tentang Pemerintahan Aceh (Lembaran Negara Republik Indonesia Tahun 2006 Nomor 62, Tambahan Lembaran Negara Republik Indonesia Nomor 4633).

Undang-Undang Republik Indonesia Nomor 21 Tahun 2001 tentang Otonomi Khusus Bagi Provinsi Papua (Lembaran Negara Republik Indonesia Tahun 2001 Nomor 135, Tambahan Lembaran Negara Republik Indonesia Nomor 4151).

\section{Sumber Lain}

Manan, Bagir, Politik Hukum Otonomi Daerah, Kuliah Umum Pada Pasca Sarjana Fakultas Hukum Universitas Syiah Kuala, Banda Aceh, 26 September 2013. http://mediaindonesia.com/news/read /120515/jadikan-batamotonomi-khusussecepatnya/2017-09-02, diakses pada tanggal 16/03/2018, pukul 06.27 wib. 